\title{
Een gegevensbank van 14de-eeuwse Middelnederlandse dialecten op computer
}

\author{
Pieter van Reenen en Maaike Mulder, Vakgroep Taalkunde, \\ Vrije Universiteit, Amsterdam, Nederland
}

Abstract: A Database of 14th Century Middle Dutch Dialects on Computer. This study describes the organization of a database, created at the Free University Amsterdam, consisting of about 2,500 charters in Middle Dutch, about 750,000 tokens. The charters were written in the Netherlands and Flanders between 1300 and 1400. Only original texts were chosen, which are dated and located. Most of them have not been published before and are to be found in the archives of The Hague, Leiden, Zwolle, Antwerp, Brussels, etc. It is shown how a charter is treated on its way from the archives to its computer format, how the data are structured and how new information - morphological coding - is added. Special attention has been paid to the way how information has been stored which is not easy to be handled on computer directly. The enriched text may be used for different purposes, not only lexicographical but even dialectal. The second part of the study serves to illustrate how the data can be exploited in view of dialect research. As an example, the verb "zullen" has been chosen. It is shown that the vowels of this verb are not the same in the different Dutch speaking areas. The results are represented on dialect maps.

Keywords: CHARTERS, COMPUTER FORMATS, COMPUTERIZATTON, DUTCH, ELECTRONIC LANGUAGE DATA BASE, ETYMOLOGY, GRAMMATICAL ANALYSIS, LEXICOGRAPHY, MANUSCRIPTS, MIDDLE DUTCH DIALECTS, PRONUNCIATION, SEMI-AUTOMATIC CODING OF TEXT

Samenvatting: Deze stude beschrijft de organisatie van een databank, aangelegd aan de Vrije Universiteit Amsterdam, van ongeveer 2.500 Middelnederlandse oorkonden, bij elkaar zo 'n 750.000 tokens. De oorkonden zijn geschreven in Nederland en Vlaanderen tussen 1300 en 1400. Alleen originele teksten zijn gekozen, die gedateerd zijn en waarvan de plaats van herkomst bekend is. De meeste zijn nooit eerder gepubliceerd, en zijn afkomstig uit de archieven van Den Haag, Leiden, Zwolle, Antwerpen, Brussel, etc. Getoond wordt hoe een oorkonde wordt behandeld van archief tot computerformaat, hoe de gegevens gestructureerd zijn en hoe nieuwe informatie - morfologische codering - wordt toegevoegd. Speciale aandacht wordt besteed aan de manier waarop informatie is opgeslagen die niet makkelijk direct door de computer kan worden verwerkt. De verrijkte tekst kan voor verschillende doeleinden worden gebruikt, niet alleen leksikografisch maar ook dialectaal. Het tweede deel van de studie laat zien hoe de gegevens kunnen worden aangewend voor dialectonderzoek. Bij wijze van voorbeeld is het werkwoord "zullen" 
gekozen. Getoond wordt dat de klinkers van dit werkwoord niet hetzelfde zijn in de verschillende Nederlands sprekende gebieden. De resultaten worden weergegeven op dialectkaarten.

Sleutelwoorden: COMPUTER FORMATEN, COMPUTERISERING, ELECTRONISCHE TAALGEGEVENSBANK, ETYMOLOGIE, GRAMMATIKALE ANALYSE, LEKSIKOGRAFIE, MIDDELNEDERLANDSE DIALECTEN, NEDERLANDS, OORKONDEN, SEMI-AUTOMA. TISCHE CODERING VAN TEKST, TEKSTEN, UITSPRAAK

\section{Inleiding}

Wie de oudste fase van de dialecten in het hele Nederlandse taalgebied toegankelijk wil maken voor onderzoek kan niet verder teruggaan dan de 14de eeuw. 1 Pas in die eeuw zijn van Groningen tot Zuid-Limburg en West-Vlaanderen voldoende teksten voor dat onderzoek bewaard gebleven: originele oorkonden waarvan de datum en plaats van redactie bekend is. Figuur 1 laat zo in oorkonde zien. ${ }^{2}$

De oorkonden zijn in groten getale te vinden in de Nederlandse en Belgische archieven. Wij sporen ze daar op, maken een selectie en fotograferen ze. Op het ogenblik (eind maart 1993) hebben we ruim 2.500 oorkonden bij elkaar, ongeveer 750.000 tokens.

Deze teksten lenen zich uitstekend voor taalkundig en leksikografisch onderzoek. Vanuit het oogpunt van de computer maakt het in wezen niet uit om welk type onderzoek het gaat, al zijn er wel graduele verschillen.

De processen en methoden die hieronder worden beschreven hebben dus niet alleen zuiver linguistische toepassingen maar ook leksikografische. In de taalkunde kan daarbij worden gedacht aan etymologisch onderzoek, in de leksikografie aan het ontwerpen van woordenboeken voor oudere taalfasen.

Wij willen aan dat corpus veelvuldig en systematisch taalkundige informatie onttrekken met het oog op een onderzoek naar uitspraakverschillen tussen de dialecten binnen een precies in de tijd afgebakende periode. Om dat te bereiken hebben wij het corpus op computer gebracht, van extra informatie voorzien, en in verband met de bevraging en verrijking van het corpus pro-

1 Het onderzoek maakt deel uit van het onderzoeksprogramma Corpusgebaseerde Woordanalyse Vulet 88/9. Het corpus is mede tot stand gekomen dankzij NWO/ST 300166-011. Jan Berns, Ton Goeman en Henk Meijering zijn wij dankbaar voor suggesties ter verbetering van deze studie.

2 In de 13de eeuw vinden we ook al heel wat oorkonden, maar die zijn voomamelijk uit Vlaanderen afkomstig, zie Gysseling (1977). V́erder zijn uit de 13de en 14de eeuw literaire teksten bewaard gebleven, maar die vermelden - in tegenstelling tot oorkonden - meestal hun plaats en datum van ontstaan niet. Bovendien zijn het vrijwel nooit originelen, en weten we niet hoe letterlijk ze zijn gecopieerd. Daarom kunnen ze, in tegenstelling tot originele oorkonden, niet dienen als primaire getuigen voor het dialectonderzoek. 
grammatuur ontwikkeld. Alle oorkonden zijn nu op computer beschikbaar. Dat is veel werk geweest, ook veel extra denkwerk over bits en bytes, maar een andere keus hadden we niet. Zonder computer zou ons onderzoek niet haalbaar zijn. Hadden we volstaan met alleen maar transcriberen en collationeren van de oorkonden, dan zouden ze alle 2.500 nog steeds zo goed als onbruikbaar zijn geweest voor dialect- en diachroon onderzoek. We hadden een onderzoeksinspanning moeten leveren die het menselijk vermogen eenvoudig te boven gaat. Daarom is het onderzoek dat wij beogen nooit eerder van de grond gekomen. En wat wij nu tot stand brengen moet ook voor het nageslacht zorgvuldig bewaard blijven als uitgangsbasis voor uitbreiding en verder onderzoek op het gebied van de taalkunde en de leksikografie. Bij de aanleg van het corpus op computer en de ontwikkeling van de programmatuur is daar zoveel mogelijk rekening mee gehouden.

Ten eerste worden zoveel mogelijk algemene normen gehanteerd. Al zijn die er nog steeds niet veel, waar mogelijk wordt bij de aanleg van het corpus en de ontwikkeling van de programmatuur gewerkt volgens richtlijnen van het Text Encoding Initiative (TEI) en de Stichting Tekstcorpora en Databestanden in de Humaniora (STDH). Standaardizering van procedures werkt op termijn drempelverlagend en werkbesparend voor de onderzoekers.

Een tweede uitgangspunt is dat alles wat de linguist aan informatie uit de oorkonden wil bewaren in een of andere vorm ook op de computer terecht komt. Het komt nog steeds veel voor - tot schade van het onderzoek - dat gegevens worden opgeofferd, omdat dat makkelijker werken op de computer zou zijn. Veel zogenaamde data-base benaderingen lijden aan dit euvel. Zij hebben veel weg van het beruchte bed van Procrustus. Bij de opslag op computer hoeft helemaal geen informatie verloren te gaan. Onze teksten worden daarom in hun geheel opgeslagen.

Ten derde is de ontwikkelde programmatuur modulair: taalgebonden componenten (bijvoorbeeld de Franse of Latijnse component) kunnen worden vervangen door andere taalgebonden componenten (de Nederlandse component) zonder dat de programmatuur op andere punten hoeft te worden aangepast. Op het ogenblik werkt de programmatuur met Middelnederlands, Oudfrans, Modern Frans, Arabisch, Latijn of Middelnederduits. Ook de opslag en verwerking der gegevens op computer is modulair. Een zoekcomponent kan onafhankelijk van een opslagcomponent worden aangepast of vervangen. Bovendien is de programmatuur zo veel mogelijk machine-onafhankelijk. Zo kan het overzetten van corpus en van programmatuur naar andere computersystemen met een minimum aan problemen tot stand komen.

Tenslotte moet de aanleg en verrijking van het corpus, gezien het vele handwerk, zo efficiënt mogelijk verlopen. Door alle handelingen zo eenvoudig mogelijk te houden kunnen we tijd en moeite sparen danwel onze productie verhogen. Met het oog hierop hebben wij een algemeen tekstformaat gedefinieerd: het invoerformaat. Het aanleveren van teksten in invoerformaat geeft de linguist of leksikoloog het minste werk, maar maakt dit formaat daarmee 
nog niet geschikt voor ondervraging van het corpus met computerprogrammatuur. Daartoe moet het corpus eerst worden omgezet in het computerformaat. Invoer- en computerformaat bevatten nog niet alle informatie die de linguist of leksikoloog in de tekst zou willen aantreffen. Wij zouden onze teksten op zijn minst morfologisch gekodeerd willen zien, te zijnertijd ook syntactisch. De morfologische kodering wordt in ons corpus semi-automatisch tot stand gebracht. Het resultaat noemen we een tekst in onderzoeksformaat. Pas dan kan het onderzoek naar middeleeuwse dialecten goed beginnen.

In het vervolg zullen wij in sectie 2 nader aandacht schenken aan de opbouw van ons corpus: wat is precies de informatie die wordt toegevoegd en hoe wordt het ene formaat in het andere omgezet. Voor een technischer en uitvoeriger behandeling van dit aspect wordt verwezen naar Huber (1989). Alle inspanningen hebben tot doel te komen tot resultaten die we anders niet hadden kunnen bereiken. Het is in dit stadium al duidelijk dat een van de resultaten die al heel eenvoudig verkregen kunnen worden een woordenlijst is die, met verwijzing naar kontekst, een mooie aanzet vormt voor het maken of aanvullen van een Middelnederlands woordenboek. Maar er kan veel meer. In sectie 3 laten wij zien met welk gemak dialectgegevens kunnen worden aangemaakt, mede dankzij het kaartontwerp van E. Wattel, zie Wattel (1990). Bij wijze van voorbeeld geven wij een paar kaarten van de klinkers van het werkwoord zullen. Ze zijn' tot stand gekomen met behulp van frekwentietabellen, die (vrijwel) automatisch uit het corpus kunnen worden gedestilleerd. Een paar samenvattende tabellen staan ook in de tekst. Bij wijze van contrast bezien we onze resultaten kort in het licht van eerdere publikaties.

2. Het oorkondenbestand op computer: van archiefstuk tot onderzoeksformaat

Zoals een rups een pop wordt, en een pop een vlinder, zo verandert ook een oorkonde van vorm. Van archiefstuk tot object van taalkundig of leksikografisch onderzoek op computer onderscheiden we vijf stadia:

Archiefstuk $>$ transcriptie $>$ invoerformaat $>$ computerformaat $>$ onderzoeksformaat

Tot en met invoerformaat gaat het om puur handwerk. Het wordt besproken in 2.1. Het omzetten van invoerformaat in computerformaat gaat volautomatisch. Hoe wordt besproken in 2.2. Het onderzoeksformaat komt interactief tot stand, dat wil zeggen semi-automatisch, zie 2.3. In deze sectie zal ook de disambiguering van homografen worden behandeld. 


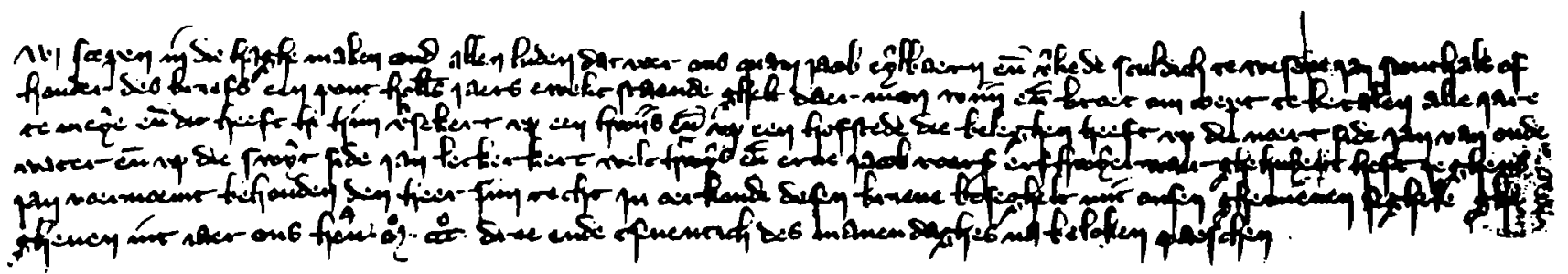

[1] Wj scepen in die haghe maken cond allen luden dat voer ons quam jacob eylbaern en(de) v(er)liede sculdich te wesene jan stouthals of

[2] houder des briefs een pont holl(an)s jaers ewelic staende ghelt daer men wiin en(de) broet om coept te betalen alle jare

[3] te meye en(de) dit heeft hi hem versekert vp een hwijs en(de) vp een hofstede die beleghen heeft vp die noert side jan van oude+

[4] water en(de) vp die swyt side jan leckerkerc welc hwys en(de) erue jacob voerseit erfhuyerwaer ghehuyert heft jeghens

[5] jan voernoemt behouden den heer siin recht jn oerkonde desen brieue beseghelt mit onsen ghemienen seghele ghe+

[6] gheuen int iaer ons $\mathrm{h}(\mathrm{er}) \mathrm{en} \mathrm{M}$ ccc drie en(de) tseuentich des manendaghes na beloken paeschen

Figuur 1: Een oorkonde met transciptie uit Den Haag van 1373.

Archief: Tafel van de Heilige Geest. Inv. 590. 


\subsection{Van archiefstuk tot invoerformaat}

De weg van archiefstuk tot oorkonde in invoerformaat moet zo snel mogelijk worden afgelegd. Het is veel handwerk dat niet kan worden geautomatiseerd. Wij bespreken kort hoe de selectie, transcriptie en verrijking van de oorkonden in dit stadium tot stand komt.

\subsubsection{Selectie van archiefstukken}

De grote meerderheid van onze 14de-eeuwse oorkonden is niet uitgegeven en moet van (foto's van) de perkamenten originelen in de archieven worden overgeschreven en gecollationeerd (papieren dokumenten zijn nog heel zeldzaam). In de archieven kiezen wij zo mogelijk zo 'n 100 oorkonden per plaats, gelijkelijk over de eeuw verdeeld. Wij selecteren bij voorkeur goed leesbare teksten, wat in de tweede helft van de eeuw meestal geen probleem geeft: er is overvloed aan keuze. We streven geen volledigheid na, zoals Gysseling (1977) heeft gedaan voor de 13de eeuw, daarvoor is er te veel materiaal en te weinig tijd beschikbaar (we zijn al 10 jaar bezig!). Soms kunnen we gebruik maken van bestaande tekstuitgaven, bijvoorbeeld Erens (1950, 1952), Moors (1952), Vangassen (1964). We kiezen alleen teksten die plaatselijk of regionaal taalgebruik bevatten, dat wil zeggen ze moeten zelf vermelden uit welke plaats of streek zij afkomstig zijn. Alleen in Drente hebben we geen plaatselijke oorkonden kunnen vinden en hebben we ons tevreden gesteld met streekgebonden oorkonden, en de onderscheiden streken zijn vrij groot. Ook elders - bijvoorbeeld in Noord-Brabant - onderscheiden wij naast plaatsen wel regio's, maar die zijn dan vaak beperkt in omvang.

\subsubsection{Transcriptie van de oorkonden}

Wij slaan de documenten niet als foto's op computer op, maar wij transcriberen ze diplomatiek: $u$ blijft $u$ (bijvoorbeeld in ghegheuen), $v$ blijft $v$ (bijvoorbeeld in $v s$ ), hoofdletters en kleine letters uit het origineel blijven gehandhaafd, leestekens eveneens, aaneengeschreven woorden blijven aaneengeschreven (vanden is heel frekwent). Enzovoort. Wij laten codicologische en paleografische aspecten buiten beschouwing en doen ook geen onderzoek naar zegels of handen. Wel kiezen wij zo veel mogelijk verschillende handen, voorzover daarvoor in een archief voldoende materiaal beschikbaar is. Na transcriptie van het perkament, kan een oorkonde eruit zien als in figuur 2. 


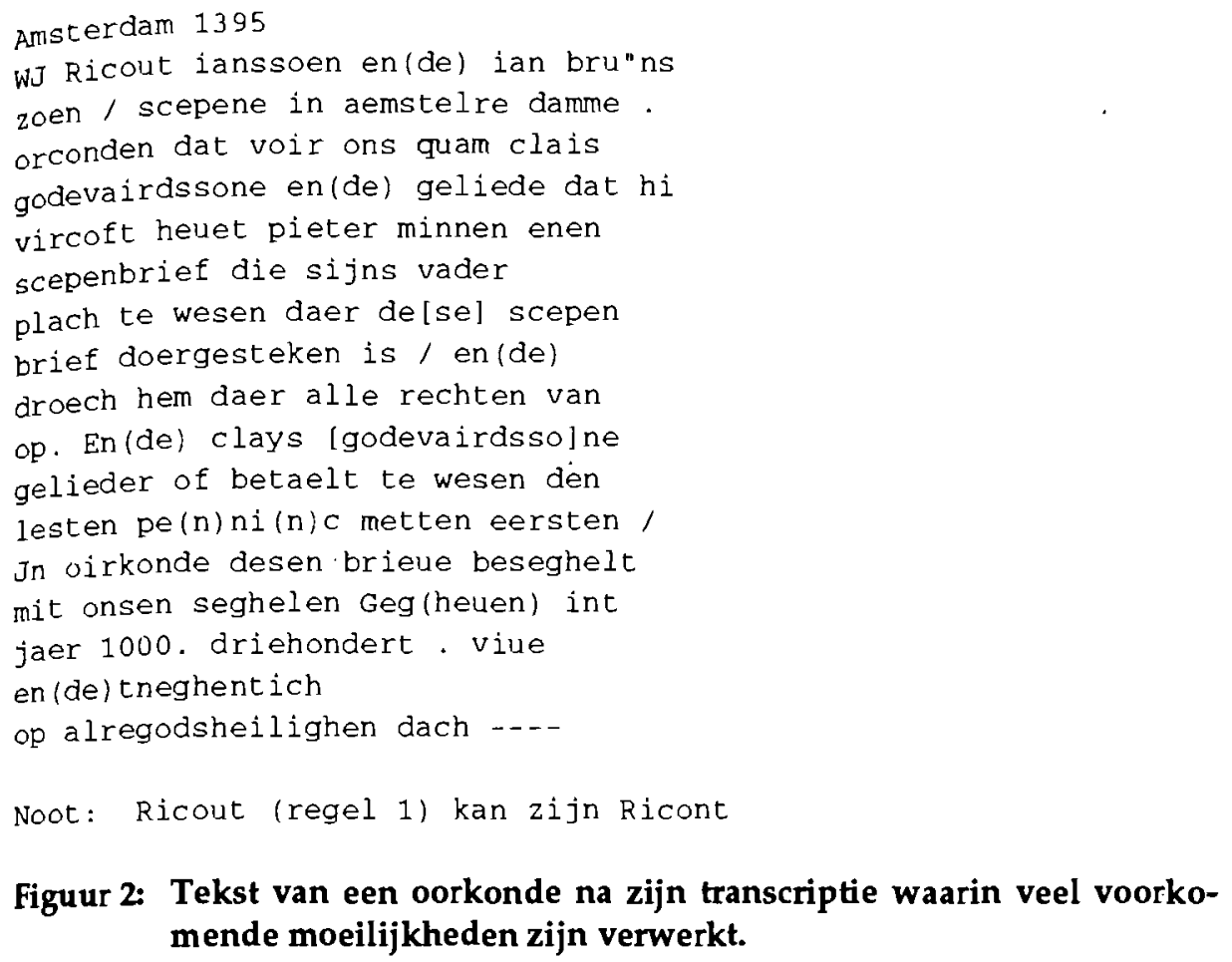

Noot: Ricout (regel 1) kan zijn Ricont

Figuur 2: Tekst van een oorkonde na zijn transcriptie waarin veel voorkomende moeilijkheden zijn verwerkt.

\subsubsection{Identificatie van teksten}

De Middeleeuwse teksten moeten stuk voor stuk makkelijk zijn te herkennen en terug te vinden. In de meesten archieven zijn ze dat ook, maar voor ons taalkundig of leksikografisch onderzoek hebben we een andere klassifikatie nodig, waarin in elk geval plaats van herkomst en tijd van redactie zijn verwerkt. Wij hebben dat uniform voor alle dokumenten opgelost door middel van een letter-cijfercombinatie, bijvoorbeeld_o:E109`39509, zie figuur 3. Die zit als volgt in elkaar.

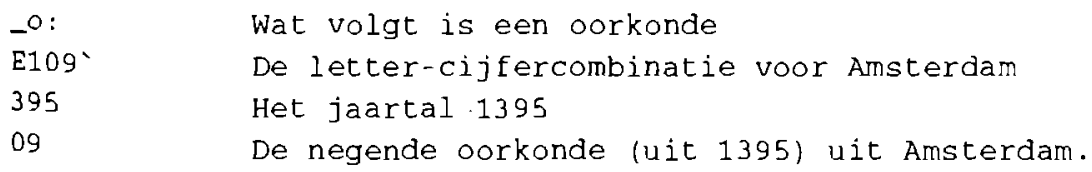

De plaats-tijdcode hoeft maar eenmaal boven de oorkonde vermeld te worden en geldt tot de volgende oorkonde, die weer met_o: begint.

Later kan op elk gewenst moment de _o:code automatisch aan alle swoorden van de betrokken oorkonde gekoppeld worden. Hoe, daar gaan wij hier nu niet verder op in. 
Letter-cijfercombinaties als E109 geven aan om welk dialect het gaat volgens de klassifikatie van Kloeke. Zo kunnen de middeleeuwse gegevens op dialectkaarten worden geplot en is vergelijking mogelijk met dialectgegevens van andere herkomst, bijvoorbeeld uit het hedendaagse Nederlands. ${ }^{3}$ Een voorbeeld hiervan wordt in sectie 2 gegeven.

Tussen het Kloekenummer en het jaartal staat een "', een dummy. Er had ook een $a$, een $b$ etc. kunnen staan, want het Kloekenummer heeft wel eens een extensie (het gaat dan om een later aan de lijst toegevoegde plaats). Zelf hebben wij vaak een $r$ toegevoegd ter aanduiding van regio. De regio krijgt het nummer van de centrale plaats binnen de regio, waarbij wij het Kloekenummer met 500 hebben verhoogd. Dat geeft nooit problemen met het aantal cijfers dat blijft altijd drie -, want het Kloeknummer is altijd lager dan 500. E109 is een plaats (Amsterdam), E609 is diezelfde plaats gelegen in de regio (regio Amsterdam). De dummy "' zorgt ervoor dat alle nummers even lang zijn, ook als er geen extensie nodig is: 10 karakters. Die uniformiteit is heel belangrijk voor latere computerbewerkingen.

Met letter-cijfercombinaties als E109`39506 identificeren wij ieder dokument ondubbelzinnig. Bovendien geven wij tegelijk plaats of regio van herkomst en het jaar binnen het millennium (van 1000 tot 1999) aan.

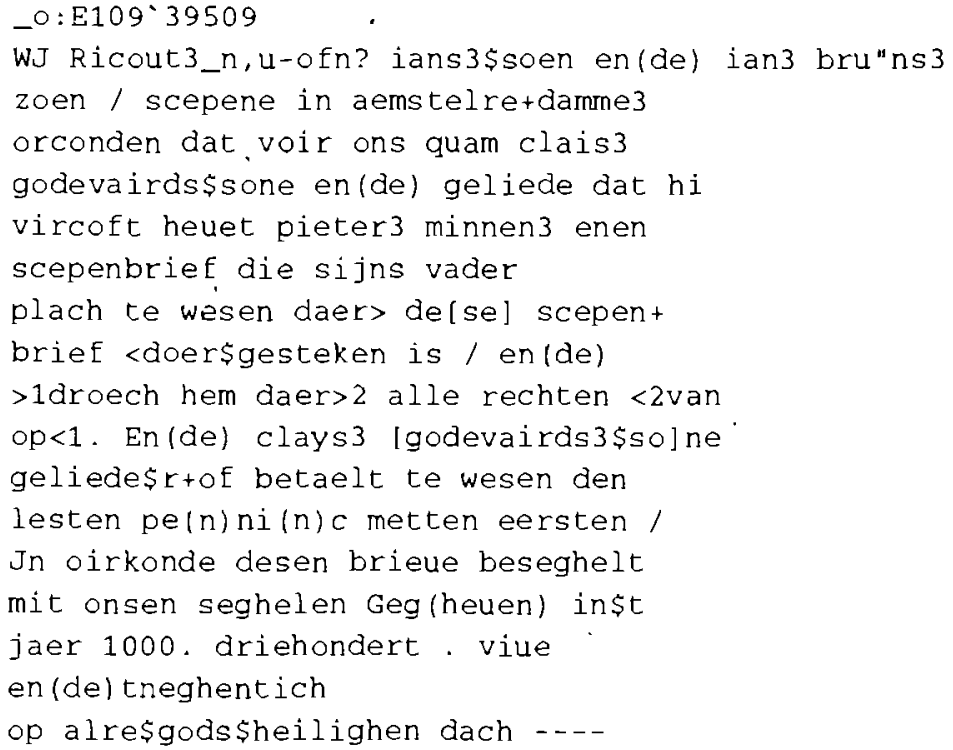

Figuur 3: De oorkonde uit figuur 2 in invoerformaat

3 Dit corpus is eveneens beschikbaar aan de Vrije Universiteit, die voor dit project samenwerkt met het P.-J. Meertens-Instituut. 


\subsubsection{Speciale tekens}

In de oorkonden komen speciale, typisch middeleeuwse tekens voor. De "/" bijvoorbeeld is een zogenaamde Duitse komma. De Umlaut in Bru" $n s$ staat in het origineel op de klinker, wij zetten hem erachter. Er zijn meer van zulke superscripten, zoals " $\wedge$ ", dat (toevallig) staat voor een hoog geschreven " $\mathrm{o}$ ". Andere symbolen van deze aard kunnen zonodig vrijelijk worden toegevoegd. Een lijst van zulke conventies moet per project worden bijgehouden. Uitsluitend standaard ASCII wordt gebruikt.

\subsubsection{Aanvullingen op de transcripties: afkortingen en verminkte passages}

Afgekorte passages die zijn aangevuld of verminkte tekst die is hersteld staat tussen [ ] of ( ). De ( ) worden gebruikt om aan te geven dat er een afkorting in het middeleeuwse handschrift stond die door de moderne uitgever is opgelost. De [ ] omgeven passages uit het origineel die niet leesbaar zijn, maar waarvan kon worden gereconstrueerd wat er gestaan moet hebben.

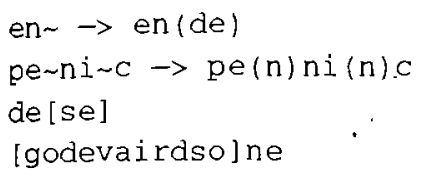

Zulke gereconstrueerde passages en opgeloste afkortingen hebben een aparte status. Ze lijken middeleeuws maar zijn het niet. Is de middeleeuwse vorm van de woorden onderwerp van onderzoek, dan kunnen we ze dus niet gebruiken. Maar we kunnen ze ook niet weglaten. Complete woordvormen en volledige zinnen zijn wel heel belangrijk bij syntactische analyse, waar de woordvorm er als zodanig niet toe doet. (Ze maken de tekst ook makkelijker begrijpelijk voor de onderzoeker.) En ze maken het semi-automatisch coderen van het tekstmateriaal, zie 2.3 , niet ingewikkelder dan nodig. Daarom verwaarlozen wij zulke tekst niet, maar geven het met behulp van de haken een speciale status.

\subsubsection{Aanvullingen op de transcripties: scheiden en samenvoegen}

Heel vaak zijn in middeleeuwse teksten woorden gescheiden of aaneengeschreven, waar wij dat niet zouden doen. Toch respecteren wij de middeleeuwse schrijfwijze. Tegelijk willen we kunnen beschikken over het moderne equivalent. Dat is makkelijker, want uniformer en bekender, en voorkomt verwarring. We slaan de brug tussen de twee systemen met koppel- en ontkoppeltekens. De $\$$ in doer $\$ g e s t e k e n$ (="door gestoken") is zo 'n ontkoppelteken, 
waar het origineel doergesteken heeft. Als koppelteken gebruiken we een "+": daarmee wordt aemstelre+damme tot een enkele eigennaam.

Bij telwoorden wordt "\%" ingevoegd als ze gescheiden in het dokument staan, als ze dat niet zijn een "H". Wij kunnen op die manier het telwoord en zijn samenstellende delen zo gewenst apart onderzoeken. Romeinse cijfers in de middeleeuwse tekst worden in de computer ingevoerd gevolgd door $g$ ("getal"). Anders kan men verkeerde dingen lezen. In figuur 2 staan geen voorbeelden, maar $l v i=$ ongelijk "lui" en wordt lvi_g. Arabische cijfers blijven (voorlopig) wat ze zijn. Bij telwoorden kan de voorcodering met \% en \# overbodig worden, als een aparte ontleder van telwoorden wordt ontwikkeld.

\subsubsection{Aanvullingen op de transcripties: eigennamen en fictieve woorden}

Eigennamen kunnen vaak niet automatisch als zodanig worden herkend. Is Jan de Bakker bakker of heet hij alleen maar zo? Ze worden daarom voorgekodeerd. Dat gaat heel snel, we zetten er een 3 (= eigennaam in onze invoercode) achter, zie aemstelre+damme3 in figuur 3 dat daarmee één eigennaam wordt, niet twee. Oorkonden bevatten meestal heel wat eigennamen.

Een speciaal geval vormen de fictieve woorden. Woorden in middeleeuwse tekst kunnen volledig geassimileerd zijn aan een buurwoord. Dan zijn ze dus compleet verdwenen. Wij voeren ze weer in als fictieve woorden. Dat is nodig voor de syntactische analyse en kan ook bij onderzoek naar assimilatie van pas komen. De fictieve woorden worden gevolgd door $f$ (van fictief). In nemet $t f$ ( = "neemt het") bijvoorbeeld is de tweede $t$ fictief. Het vormt een eenheid met het voorafgaande woord.

\subsubsection{Discontinue morfemen}

Voornaamwoordelijke bijwoorden en werkwoorden komen nogal eens gesplitst in twee, soms zelfs meer, elementen voor (zie figuur 2: daer ... van en droech ... op). Het inputformaat van deze woorden is vastgelegd in figuur 4 .

Het zal duidelijk zijn dat $>$ morfeem moet worden verbonden met <morfeem en morfeem $>$ met $<$ morfeem. Aangezien de posities van " $>$ " en " $<$ " het punt van koppeling aangeven, zal ook duidelijk zijn dat morfeem $>$ en <morfeem al in de volgorde staan waarin ze aan elkaar gekoppeld moeten worden, terwijl dat niet zo is bij >morfeem en morfeem<. Dus zowel begin als eind van een morfeem kunnen als koppelpunt dienen, zodat in het zeer zeldzame geval dat een derde morfeem voorkomt na de twee anderen, het derde morfeem kan worden genoteerd als <morfeem en het tweede morfeem als <morfeem >.

In de oorkonde van figur 4 is er nog een tweede complikatie, die weliswaar zelden optreedt, maar waarin toch moet worden voorzien. $1>1$ droech ... $o p<1$ en daer $>2$... $<2$ van behoren tot twee paren discontinue morfemen waar- 
van de domeinen verstrengeld zijn. In dat geval kan " $>1$ " en " $<1$ " worden gebruikt voor het eerste paar morfemen, " $>2$ " en " $<2$ " voor het tweede paar. De twee voorbeelden illustreren tevens beide volgordes. Het voornaamwoordelijk bijwoord daer ... <van heeft zijn normale volgorde. Het werkwoord opdragen heeft dat niet. Werkwoorden kunnen in twee volgordes voorkomen en een keuze moet worden gemaakt wat als de basisvolgorde wordt beschouwd. De derde persoon enkelvoud $<d r o e c h . . . ~ o p>$ in de oorkonde van figuur 3 wijkt dus af van de basisvolgorde.

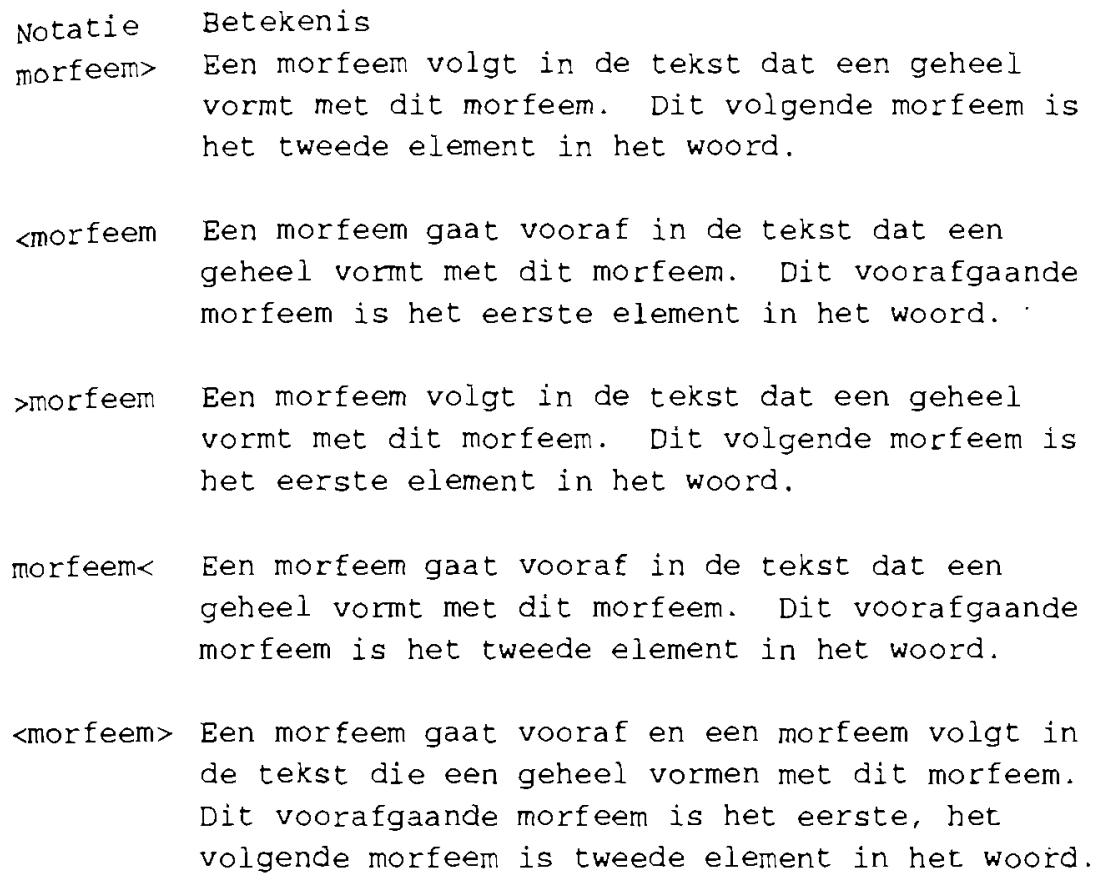

Figuur 4: Het invoerformaat van woorden bestaande uit discontinue elementen.

\subsubsection{Aanvullingen op de transcripties: noten}

De moderne uitgever heeft soms behoefte tekst en noten toe te voegen aan het middeleeuwse origineel. Noten kunnen bijvoorbeeld betrekking hebben op onzekerheid bij de transcriptie. Noten in de tekst worden voorafgegaan door - $n$. Daarachter staat ofwel korte aanvullende informatie ofwel een verwijzing naar elders. Een voorbeeld van korte aanvullende informatie is $\_n, u=n$ ? achter Ricout. Heel handig is gebruik te maken van $n$, sic voor afwijkende vormen. Het voorkomt telkens opnieuw verifiëren of de transcriptie van het origineel 
wel correct was. Informatie over de oorkonden en hun herkomst uit de archieven of over scribenten kan meteen achter het oorkondenummer $\_0$ als noot $n$ worden vermeld, zolang hier geen speciale categorie voor is voorzien.

\subsection{Van invoerformaat naar computerformaat}

Uit het invoerformaat wordt volautomatisch het computerformaat afgeleid. $\mathrm{Bij}$ het tot stand brengen van het invoerformaat moest alle informatie met zo min mogelijk handwerk voor de taalkundige of leksikograaf worden aangebracht. Voor het tot stand brengen van het computerformaat geldt een andere doelstelling: de verwerking - bevraging en verder verrijking van het materiaal, een interactief proces - zo eenvoudig mogelijk te laten geschieden. Dat kan door het formaat, zodra het op computer is, af te stemmen op de systematiek van de programmatuur. Dat betekent dat we rekening houden met noties als sorteren: een preciese vorm van alfabetiseren die letters, cijfers en leestekens betreft. Aangezien we bij het sorteren geen rekening willen houden met haakjes, hoofdletters, voorcoderingen e.d., voeren we twee grote operaties uit. We zorgen dat (a) de middeleeuwse tekst alleen met kleine letters wordt geschreven; (b) de middeleeuwse woorden intern geen toegevoegde informatie bevatten. Omdat nog steeds de eis geldt dat geen informatie mag verloren gaan, wordt de toegevoegde informatie vanaf dit stadium niet meer in, maar achter het woord opgeslagen. Middeleeuwse tekst is te onderscheiden van toegevoegde tekst door middel van het "_", zie figuur 3 en vooral figuur 5. Het streepje wordt gevolgd door een aanduiding die het type code aangeeft, bijvoorbeeld $-8=$ getal, _l=leesteken, $c=$ capitaal (hoofdletter), $\_0=0$ orkonde. De voorcodering 3 wordt hier vervangen door_e (= eigennaam): Jan $3 \rightarrow$ Jan_e. Een woord dat de onderzoeker zelf (gedeeltelijk) heeft aangevuld behoort nu in zijn geheel tot de middeleeuwse tekst. Via de code achter het woord kan worden achterhaald dat dit niet werkelijk zo is.

De metatekst, of het kommentaar, achter de diverse "-"'s is vaak karaktergeoriënteerd. Dat houdt in dat het betrekking heeft op de positie van de letters in de middeleeuwse tekststring. De positie van die letters wordt aangegeven door middel van twee soorten tellers.

Het eerste type teller geeft binnen het woord de positie aan van de letter waarop het commentaar betrekking heeft. 'Dit is bij haakjes het geval en bij hoofdletters.

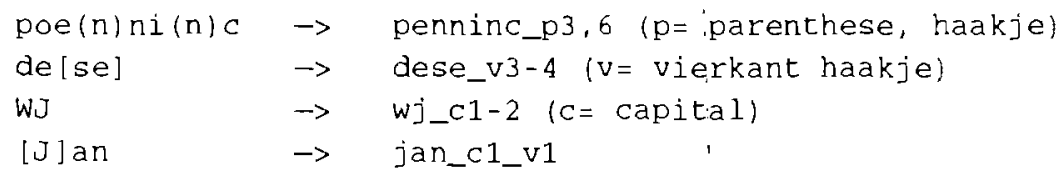


In pe(n)ni(n)c $\rightarrow$ penninc_p3,6 staan haakjes romdom letter 3 en romdom letter 6 van het woord, in delsel staan vierkante haken om letter 3 en 4 . In WJ $\rightarrow w j \_c 1$ 2 zijn de letters 1 en 2 hoofdletters.

Het tweede type teller geeft binnen het woord de positie van de letter aan die aan het te signaleren verschijnsel voorafgaat. Dit is bij discontinue elementen het geval, evenals bij koppeling en scheiding van woorden, en sommige speciale tekens.

$\begin{array}{lll}\text { doer\$gesteken } & \rightarrow & \text { doer_a4 gesteken_a0 (a=punt van aanhechting) } \\ \text { aemstelre+damme } & \rightarrow & \text { aemstelredamme_k9 (k=koppelteken) } \\ \text { bru"ns_u3 } & \rightarrow & \text { bruns_u3 (u=umlaut) } \\ \text { daer> } & \rightarrow & \text { daer_ba4 (b=begin) } \\ \text { <doer } & \rightarrow & \text { doer_ea0 (e=eind) } \\ >1 \text { droech } & \rightarrow & \text { droech_bbo } \\ \text { op<1 } & \rightarrow & \text { op_eb2 } \\ \text { daer }>2 & \rightarrow & \text { daer_bc4 } \\ <2 \text { van } & \rightarrow & \text { van_ec0 }\end{array}$

In doer\$gesteken $\rightarrow$ doer_a4 gesteken_a0 geeft "a" gevolgd door het cijfer het punt van koppeling aan. Bij droech op en daer van is er een probleem, omdat daer in de tekst tussen droech en op in staat. Om de juiste woorddelen bij elkaar te krijgen wordt droech en op daarom gevolgd door $b 0$ en $b 2$, daer en van door $c 4$ en $c 0$. In aemstelre+damme wordt "+" vervangen door "_k": aemstelredamme_k9. Bij ">" en " $<$ " worden $\_b$ (=begin) of _ $e$ (=eind) ingevoerd. Bij leestekens en arabische getallen doen we of er geen middeleeuwse tekst aanwezig is: ze komen als geheel achter het "_" te staan. Bij omzettingen komen ze er als volgt uit te zien:

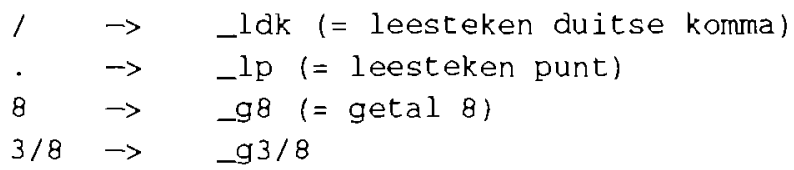

\subsection{Van computerformaat naar onderzoeksformaat: homografen}

De tekst in computerformaat wordt op zijn beurt - semi-automatisch, dat wil zeggen interactief - van morfologische kodering voorzien. Het resultaat is het onderzoeksformaat: een verzameling teksten, niet alleen gekodeerd in termen van plaats en jaar, maar bovendien voorzien van een taalkundige kode per woordvorm.

De kodes in het computerformaat beginnen allemaal met een "- gevolgd door een specifieke letter. In het onderzoeksformaat wordt alleen nog de morfologische kode toegevoegd. Die hoeft dan niet te worden voorafgegaan door een letter om van alle andere koderingen onderscheiden te zijn. 
Bij het semi-automatisch koderen van de tekst worden de te koderen vormen telkens vergeleken met een lijst van items die al eerder gelemmatiseerd zijn: werkwoorden, zelfstandige en bijvoeglijke naamwoorden, voornaamwoorden, voegwoorden, telwoorden enz. Elk lemma bestaat uit een lijst van alle verschillende morfologische vormen die er in geschreven vorm zijn, voorzover ze al in het corpus zijn voorgekomen. Naast gekodeerde tekst wordt dus een tweede output gekreëerd: een lijst van gelemmatiseerde items. Bij elkaar vormen deze twee resultaten een zeer krachtig hulpmiddel bij het systematisch onderzoek van Middelnederlands. Ongeveer de helft van ons corpus is inmiddels van een morfologische kode voorzien. Gedurende deze fase wordt de lijst van gelemmatiseerde items telkens aangevuld. Uiteindelijk ziet onze oorkonde eruit als in figuur 5, waarin zogewenst de aard van de verschillende coderingen nader kan worden gespecificeerd.

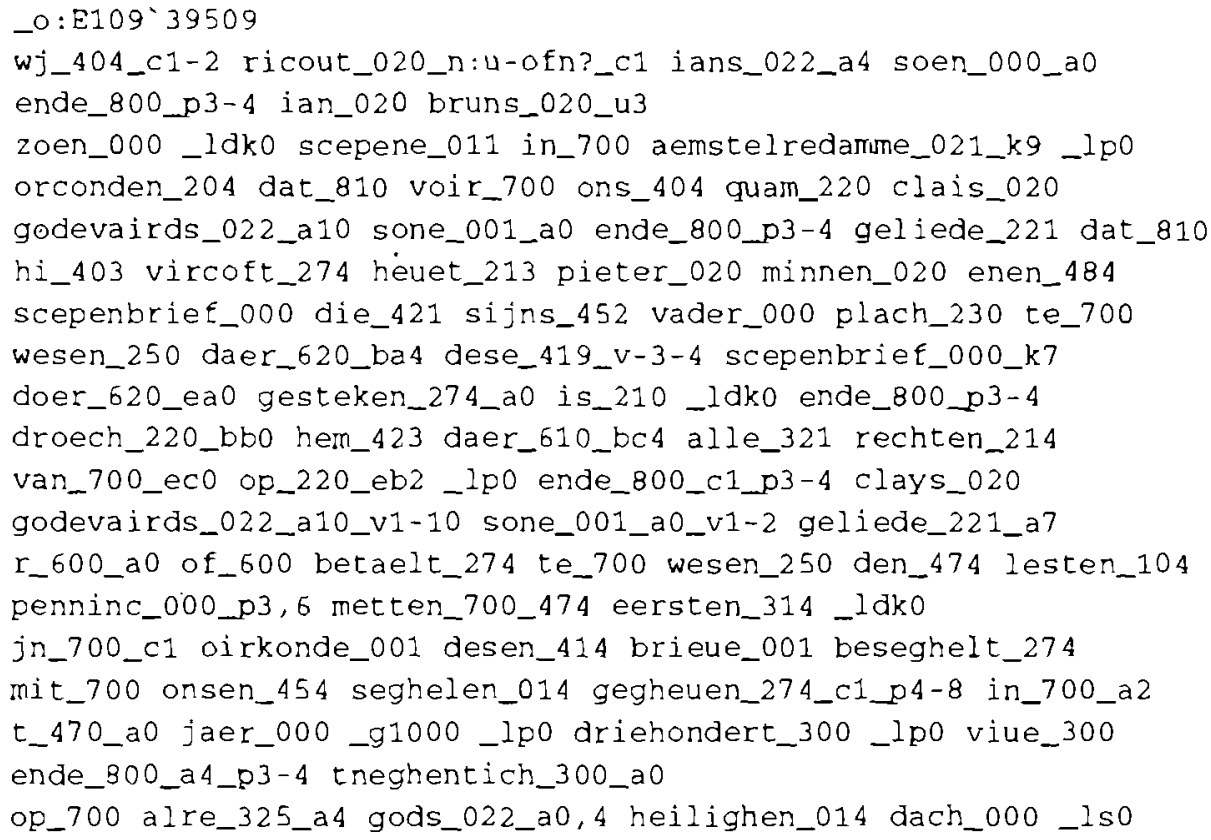

Figuur 5: De oorkonde uit figuur 3 omgezet naar onderzoeks formaat.

Een van de lastigste problemen bij het koderen is het disambigueren van homografen. Het is meestal handwerk. Soms is het handig de code al aan te brengen in het invoerformaat, zoals bij eigennamen: bakker $3=$ bakker_e versus bakker als beroep. De voorkodering moet zo kort mogelijk zijn, ter voorkoming van extra werk. Disambiguering van homografen kan ook tot stand worden gebracht tijdens het koderen. In de toekomst moet een deel van de homo- 
grafen door contekstgevoelige regels automatisch kunnen worden onderscheiden.

Zolang ze tot verschillende woordsoorten behoren, kunnen homografen worden onderscheiden door middel van de taalkundige kode. Zijn het echter allebei zelfstandige naamwoorden, of werkwoorden, dan kan dat niet. Bijvoorbeeld, er zijn twee woorden grave nl. "comes" en "gracht". Beide worden als grave_000 gecodeerd. Maar ze behoren tot verschillende lemma's. Wij lossen dit probleem als volgt op: grave_000_hl,comes en grave_000_hn, gracht, waar de " $\mathrm{h}$ " = homograaf, en de "l" voor Latijn als disambiguerende taal staat, de " $\mathrm{n}$ " voor Nederlands. De disambiguering moet zo kort mogelijk zijn, en niet in termen van etymologie.

Vergelijken we nu de figuren 1,2,3 en 5, dan zien we hoe de metamorfose van archiefstuk tot dokument in onderzoeksformaat in diverse stappen tot stand gekomen is. Verdere verrijkingen van het onderzoeksformaat blijven in de toekomst mogelijk.

\section{De klinkers van het werkwoord ZULLEN: geografische contrasten}

Als het corpus oorkonden eenmaal in onderzoeksformaat (tot op zekere hoogte ook al in computerformaat) beschikbaar is, kan het leksikografisch of taalkundig onderzoek pas goed een aanvang nemen. Veel van dat onderzoek is woordvorm- of spellingsonderzoek. Soms kan dat direct worden vertaald in klankverschillen, zonder dat er veel interpretatie aan te pas komt. Dat zullen wij in deze sectie laten zien aan de hand van de klinkers van het werkwoord zullen (dat wij hier altijd met een $z$ zullen schrijven: in Van Reenen en Wattel (1992) hebben wij de spelling met $s$ of $z$ bij o.a. dit werkwoord nader onderzocht). Wij beperken ons tot de infinitief en tot de eerste en derde persoon enkelvoud en meervoud van de tegenwoordige tijd. We vinden hier in het meervoud korte of lange klinker, $0, u, e$, en in het enkelvoud zal of zel.

Op basis van een serie kleine programma's hebben wij automatisch tabellen tot stand gebracht waarin het voorkomen van zal en zel, van zullen, zellen, zelen, zolen, zoelen is vastgelegd in termen van plaats en tijd, in totaal meer dan 2.000 vormen.4

De resultaten kunnen op kaarten worden weergegeven dankzij programmatuur ontwikkeld door E. Wattel, zie Wattel (1990). Voor de weergave op de kaarten heeft elke oorkonde geteld als een getuige. Een oorkonde met meer

Een kleine toelichting op de programma's voor de kenners: Het gaat om korte programmaatjes geschreven onder UNIX in de shell: egreps en AWK-programmaatjes selecteren relevante vormen en printen ze op de juiste plaats. Verder wordt gebruik gemaakt van commando's als tr en sort gecombineerd met uniq -c en join, en substitutie-commando's in de ex. Al deze features zijn standaard onder UNIX beschikbaar. Ze zijn ook op PC beschikbaar: o.a. onder MINIX of onder MS-DOS via de MKS-toolkit. 
dan een relevante vorm telt echter zwaarder dan een oorkonde met slecht één relevante vorm: 1 vorm telt voor 1, 4 vormen voor 2 , en 9 vormen voor 3 (de vierkantswortel uit het aantal voorkomens per oorkonde). In de tabel in de Appendix telt een oorkonde als een getuige, ongeacht het aantal relevante vormen.

\subsection{Zel en zal}

Een eerste resultaat betreft zel en zal. Het is te zien in tabel 1. Voor de corresponderende dialectkaart, zie Van Reenen (te verschijnen). Zel - ongetwijfeld met een [ $\varepsilon$ ]-achtige klank uitgesproken - is westelijk, maar komt ook sporadisch in Groningen voor. Van Loey (1966: $§ 68$ ) komt aardig in de richting als hij zel in Holland plaatst. Toch kent Holland ook zal, Dordrecht zelfs overwegend. En verder doet ook Utrecht flink met zel mee. In de loop van de eeuw spreidt het gebruik van zel licht naar het oosten: Amersfoort, en komt de vorm in het noorden in Groningen op. Volgens de gegevens van De VriendtDe Man (1958) komt zel in de 16de eeuw nog voor in Haarlem, maar vooral in Leiden. ${ }^{5}$

Ook in het Afrikaans is de vorm wel eens gesignaleerd, zie Ponelis (1990: $\S 4.2$ ). In het Kaapse Afrikaans is [sol] normaal. Tenslotte treffen we ook in de moderne Nederlandse dialecten nog resten van het middeleeuwse kaartbeeld aan, zie kaart 1. Weijnen signaleert de vormen ook in Gouda en Katwijk aan Zee (1958: 373,374 en 370).

\subsection{Zellen, Zelen, Zo(e)len, lange klinker en korte klinkers}

De frekwenties van de klinkers van zullen (infinitief of meervoud) staan in tabel 2 per (deel van een) provincie geordend. Zellen hoort bij zel te horen, maar vergelijking van tabel 1 en 2 laat zien dat dat geografisch niet helemaal klopt. De vorm is namelijk vooral in Utrecht te vinden, veel minder in Holland, en een

De Vriendt-De Man (1958) heeft 540 vormen verzameld waarvan $18 z e l$. Het is opmerkelijk hoe sceptisch ze staat tegenover de betrouwbaarheid van haar gegevens: "De taal der ambtelijke documenten ... wemelt van traditionele formules en archaïstische zinswendingen die dikwijls klakkeloos werden overgeschreven uit een ouder, gelijkaardig stuk". Zou zij gelijk hebben, dan heeft haar onderzoek geen zin gehad. Men vraagt zich af waarom zij het heeft uitgevoerd. Nu is vaststellen of een tekst van een 16 de-eeuwse oorkonde al dan niet klakkeloos is overgeschreven geen eenvoudige opgave. $\mathrm{Zij}$ heeft voor haar scepticisme dan ook geen overtuigend bewijs gevonden. Tot het tegendeel is aangetoond beschouwen wij daarom de informatie die zij aan deze ambtelijke dokumenten ontleent als betrouwbaar. Wel delen wij haar scepsis ten aanzien van de literaire teksten waar zij zich op baseert, zolang die niet nader in tijd en ruimte zijn geplaatst. 
enkele vorm in Noord-Brabant. In Noord-Holland lijkt zellen in de loop van de eeuw wat af te nemen, in Zuid-Holland en Utrecht wat toe. De vorm komt op in Groningen. Raadplegen we Van Loey (1966: $\S 68$ ), dan vinden we vooral in Holland en Utrecht andere accenten. Zellen zou Noordhollands zijn (p.88) en de vorm zou ook wel eens in Brabant voorkomen (p.90). Het beeld gesuggereerd in Van den Berg en Vermeulen (1973) - in belangrijke mate gebaseerd op een kleine deelverzameling van de gegevens die wij ook hebben gebruikt klopt beter. In haar 16de-eeuwse gegevens heeft De Vriendt-De Man (1958) de vormen niet meer aangetroffen.

Naast zellen is er nog een andere vorm met een e-achtige klinker. Kaart 2 laat zien dat zelen een typisch Belgisch Brabantse vorm is met als centrum Brussel. Dat vinden we ook bij Van Loey en Van den Berg en Vermeulen en Goossens (1980: 62) terug. Blijkens De Vriendt-De Man (1958: 213-232) komen ze ook in de 16de eeuw nog veelvuldig in Brussel en omgeving voor: 50 op de 109 vormen.

Uit tabel 2 blijkt verder dat zoelen en zolen oostelijke vormen zijn, zie ook kaart 3, waar zoelen en zolen samen tegenover de andere vormen zijn gekarteerd. Van Loey $(1966: 88,91)$ beschouwt solen als Limburgs en Hollands. In het licht van onze 14de-eeuwse kaart moet in Holland die vorm dan wel de laatste der Mohikanen zijn geweest, wellicht ook de eerste. De informatie van Van Loey is op dit punt zeker niet representatief. Voor 13de-eeuwse gegevens, zie ook Van Loey (1952).

Tenslotte valt uit tabel 2 de tegenstelling tussen zullen met een enkele - $l$ en zullen met een dubbele - $l l-$, af te lezen, een verschil dat algemeen wordt opgevat als tussen lange klinker en korte klinker. De vorm met dubbel -ll- (korte klinker) is duidelijk aan de winnende hand, vooral in Noord-Brabant en in het Noorden, zo leert een nadere analyse van de gegevens.

\subsection{Discussie}

Uit de kaarten en tabellen die wij hierboven hebben gegeven komt een algemeen verschil naar voren met bestaande kennis. Daar worden vanouds de dialectverhoudingen in algemene termen aangegeven, vaak vaag, een enkele keer ook te precies. Betekent een uitspraak: "Zellen komt in Holland voor", dat zullen daar niet voorkomt? Of dat zellen alleen in een deel van Holland voorkomt? En is dat dan weleens of altijd? Zelfs wanneer Van Loey een vorm met een datering geeft, kunnen we niet weten of die vorm representatief is. Verder worden veel Nederlandse dialectgebieden niet of nauwelijks vermeld: Utrecht, Gelderland en Zeeland schitteren vaak door afwezigheid. De wel vermelde streken zijn soms wel erg groot en niet altijd precies afgebakend: Holland, Brabant, Limburg en Vlaanderen.

Overigens worden Gelderland, Overijssel, Drente en Groningen niet altijd tot het Middelnederlandse taalgebied gerekend, al hebben wij ze wel onder- 
zocht. Ook Friesland valt erbuiten. Onze kaarten suggereren dat in Friesland $z e l$ - en zellen-achtige vormen moeten hebben voorgekomen. Raadpleging van Vries (1977) leert dat dit klopt. Het middeleeuwse Fries kent skel en sel, skellen en sellen.

\section{Conclusie}

Deze studie valt uiteen in twee delen. Het eerst deel had tot doel te laten zien hoe grote bestanden middeleeuwse teksten op computer kunnen worden opgeslagen en zinvol worden ingericht. De inrichting van de bestanden maakt duidelijk hoe de taalgegevens betrekkelijk eenvoudig kunnen worden gebruikt met het oog op o.a. leksikografisch onderzoek. In het tweede deel werd daarom kort een ander aspect van het taalmateriaal belicht dat onvermijdelijk, bij gebrek aan een standaardtaal, door alle taal- en leksikografisch onderzoek uit die periode heen speelt: de spreiding der gegevens in de ruimte (en de tijd). Getoond werd - aan de hand van de klinkers van het werkwoord zullen wat dit type onderzoek aan resultaten kan opleveren. Door grote aantallen gegevens te destilleren uit gedateerde en plaatsgebonden taalgetuigen en die te systematiseren op dialectkaarten en in tabelvorm, kan onze kennis van het Middelnederlands niet alleen taalkundig maar ook leksikografisch met sprongen toenemen.

\section{Verwijzingen}

De Vriendt-De Man, M.J. 1958. Bijdrage tot de kennis wan het gebruik en de flexie van het werkwoord ZULLEN in de 16de eeuw. Koninklijke Vlaamse Academie voor Taal- en Letterkunde, Reeks VI, Nr. 81. Gent.

Erens, M.A. 1950, 1952. De oorkonden der Abdij van Tongerloo II, III. Tongerloo: St. Norbertsdrukkerij.

Goossens, J. 1980. Middelnederlandse vocaalsystemen. VMA, afl. 2.

Gysseling, M. 1977. Corpus van Middelnederlandse Teksten (tot en met het jaar 1300). Reeks I: Ambtelijke Bescheiden. 's-Gravenhage: Martinus Nijhoff.

Huber, O.C. 1989. The Construction of Lexically Analyzed Text Corpora on the Computer. -Corpus Based Word Analysis, Report \#1, Vakgroep Taalkunde, Vrije Universiteit, Amsterdam.

Moors, Joseph. 1952. Bouwstoffen tot de historische toalgeografie van het Nederlands, $I$, De oorkondentaal in Belgisch-Limburg. Belgisch Interuniversitair centrum voor Neerlandistiek.

Ponelis, F.A. 1990. Historiese klankleer van Afrikaans. Universiteit van Stellenbosch, Annale 1.

Van den Berg B. en A.G.M. Vermeulen. 1973. 'Zullen' als proefgeval. De Nieuwe Taalgids 66: 445452.

Vangassen, H. 1964. Bouwstoffen tot de historische taalgeografie van het Nederlands, VIII, Noordhollandse charters. BeIgisch Interuniversitair centrum voor Neerlandistiek.

Van Loey, A. 1952. Een en ander over Mnl. Sullen. VMA: 919-922. 
Van Loey, A. 1966. Middelnederlandse spraakkunst I. Vormleer, 5de druk. Groningen: Wolters.

Van Reenen, P. Te verschijnen. The Study of Medieval Language in the Low Countries: the Good, the Bad and the Future. Medieval Dialectology, Workshop Taxonomy and Typology in Medieval Dialect Studies. Edinburgh, April 1992.

Van Reenen, P. en E. Wattel. 1992. De uitspraak van /s/ en /z/ voor klinker in het Nederlands: zes eeuwen variatie. Bennis, H.J. en J. de Vries. (Red.). 1992. De binnenbouw oan het Nederlands: 291-309. Dordrecht: ICG Publications.

Vries, O. 1977. Oudfriese oorkonden. Vierde deel. (Oudfriese taal- en rechtsbronnen uitgeven door dr. P. Sipma. Veertiende deel.) 's-Gravenhage: Martinus Nijhoff.

Wattel, E. 1990. A Mathematical Model to Describe the Boundary of a Vowel Shift in the Past on the Basis of Data from Contemporary Dutch Dialects. Rapportnr. WS -359, Mei 1990, Vrije Universiteit Amsterdam.

Weijnen, A. 1958. Nederlandse dialectkunde. Assen: Van Gorcum. 


\section{Appendix}

\begin{tabular}{rrrl}
\hline 1 & 2 & 3 & 4 \\
\hline & zal & zel & provincie \\
& & & \\
01 & 6.5 & 1.5 & 01 = Groningen $/$ Drente \\
02 & 10 & 0 & 02 = Overijssel \\
03 & 11 & 0 & 03 = Gelderland \\
04 & 11 & 17 & 04 = Utrecht \\
05 & 8.5 & 11.5 & $05=$ Noord-Holland \\
06 & 4 & 6 & 06 = Zuid-Holland West \\
07 & 3 & 2 & 07 = Zuid-Holland Oost \\
08 & 1 & 0 & 08 = Zeeland \\
09 & 6 & 1 & 09 = Noord-Brabant West \\
10 & 18 & 0 & 10 = Noord-Brabant Oost \\
11 & 7 & 0 & 11 = Limburg \\
12 & 1 & 0 & 12 = West-Vlaanderen \\
13 & 2 & 0 & 13 = Oost-Vlaanderen \\
14 & 3 & 0 & 14 = Antwerpen \\
15 & 4 & 0 & $15=$ Brabant \\
16 & 23 & 0 & 16 = Belgisch Limburg
\end{tabular}

Tabel 1: Frekwentie van zal en zel in het 14de-eeuws Middelnederlands.

\begin{tabular}{llllllllll}
\hline 1 & 2 & 3 & 4 & 5 & 6 & 7 & 8 & 9 & 10 \\
\hline
\end{tabular}

prov zullen zellen zelen zoelen zolen zuelen zulen zollen zoellen

$\begin{array}{lrrrrrrrrr}01 & 26.6 & 6.2 & 0.5 & 6 & 33.5 & 0 & 0 & 1.2 & 0 \\ 02 & 18.07 & 0 & 0 & 33.87 & 29.56 & 0 & 5.5 & 0 & 1 \\ 03 & 2.83 & 1 & 0 & 15.25 & 38.31 & 19.48 & 6.13 & 1 & 0 \\ 04 & 11.33 & 110.17 & 0 & 18 & 1 & 0.5 & 0 & 0 & 0 \\ 05 & 49.83 & 15.17 & 0 & 0 & 0 & 0 & 0 & 0 & 0 \\ 06 & 20.64 & 8.36 & 0 & 0 & 0 & 0 & 0 & 0 & 0 \\ 07 & 40.47 & 2.53 & 0 & 0 & 1 & 0 & 0 & 0 & 0 \\ 08 & 50 & 0 & 0 & 0 & 0 & 0 & 0 & 0 & 0 \\ 09 & 12.89 & 4.11 & 7 & 4 & 1 & 0 & 0 & 0 & 0 \\ 10 & 29.39 & 0 & 2 & 24.22 & 15.39 & 0 & 1 & 1 & 0 \\ 11 & 10.5 & 0 & 0 & 2.62 & 18.88 & 20 & 2 & 0 & 0 \\ 12 & 71 & 0 & 0 & 0 & 0 & 0 & 0 & 0 & 0 \\ 13 & 32.25 & 1 & 0.75 & 0 & 0 & 0 & 0 & 0 & 0 \\ 14 & 0 & 0 & 7.5 & 2.83 & 2.67 & 1 & 0 & 0 & 0 \\ 15 & 1 & 0 & 40 & 0 & 2 & 0 & 0 & 0 & 0 \\ 16 & 19 & 0 & 3.5 & 46.32 & 44.76 & 9.42 & 1 & 0 & 1\end{array}$

Tabel 2: De klinkers van het werkwoord zullen in 14de-eeuws Middelnederlands 


\section{Kaart 1: Verdeling zel (donker gebied) versus zal in 14de-eeuws Middel-} nederlands.

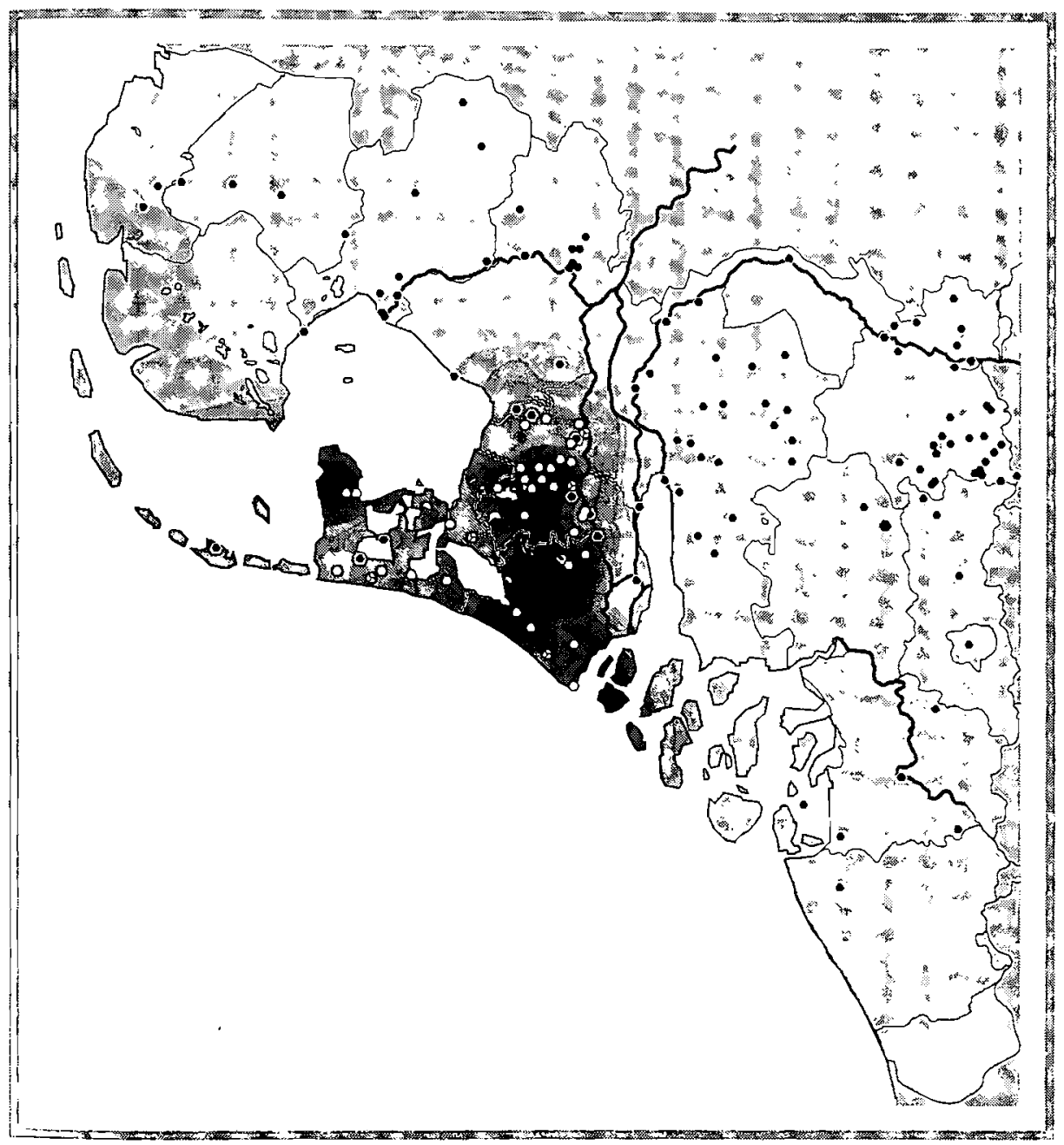




\section{Kaart 2: Spelling zelen (donker) versus andere vormen van zullen.}

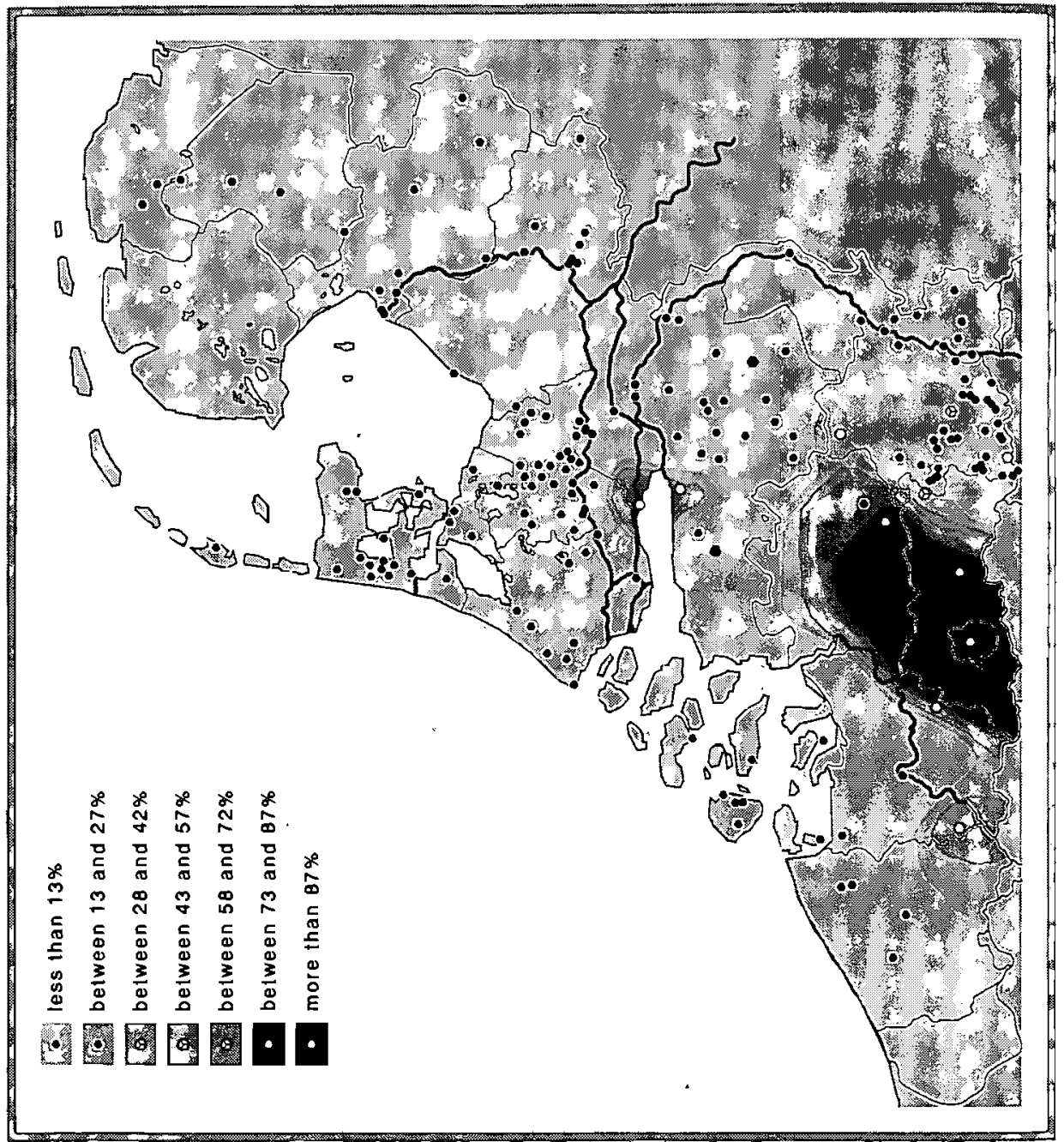




\section{Kaart 3: Spelling zolen of zoelen (donker) versus andere vormen van zullen.}

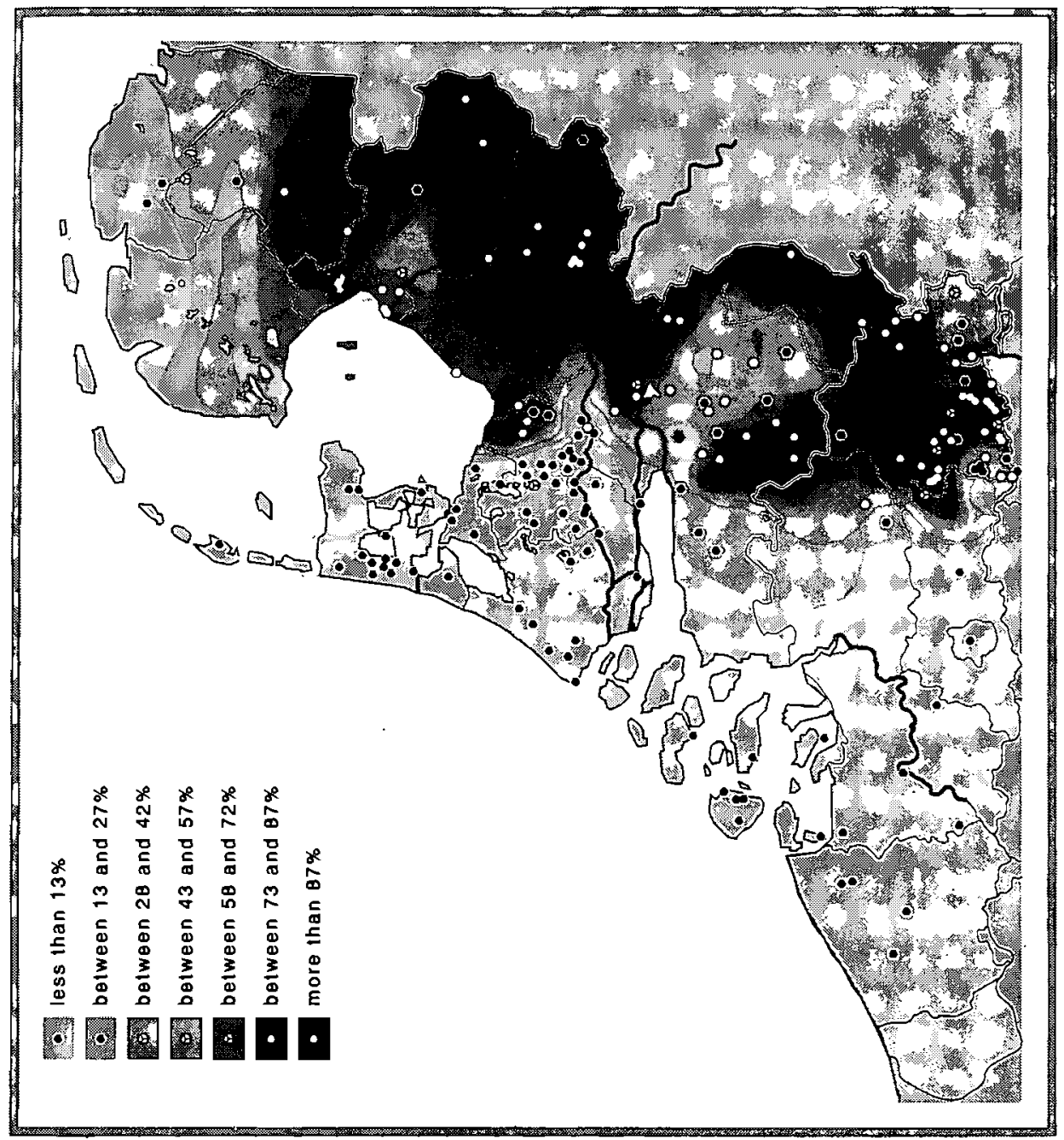

